UDC 346.548(4-672 EU)

DOI: $10.5937 /$ RKSPP2101095P

ANDREA PILETTA MASSARO

\title{
THE NEW DIRECTIVE ON AN EU-WIDE REPRESENTATIVE ACTION AND THIRD-PARTY LITIGATION FUNDING: AN OPPORTUNITY FOR EUROPEAN CONSUMERS?
}

After years of compensatory collective redress being left to a sort of regulatory competition among Member States, Directive 1828/2020 finally introduced an EU wide representative action scheme, aimed at strengthening the position of European consumers vis-à-vis new market dynamics such as globalisation and digitalisation. The new system, which shall run in parallel with national tools, introduces some innovations such as a cross-border action mechanism, the possibility of adopting an opt-out model and a specific regulation of thirdparty litigation funding in the context of collective redress. This aspect, addressed already in the 2013 Recommendation, is of particular interest, because third party funding represents a particularly powerful complement to collective redress in easing citizens' access to justice. However, the provisions introduced with Directive 1828/2020 leave some issues open. In particular, the Court's role in managing the funding agreement, with special reference to the funder's fee, and the effect of the funding agreement in case an opt-out adhesion mechanism is adopted are of paramount importance and still need to be addressed interpretatively. In

Andrea Piletta Massaro, research fellow at the University of Turin, Italy (Compagnia di Sanpaolo's Why Europe? Project), and at the Turin Observatory on Economic Law and Innovation (TOELI).PhD candidate at the University of Trento, Italy, e-mail addresses: andrea.piletta@unito.it / andrea.pilettamassaro@unitn.it. This article is linked to the paper "Towards an EU-Wide Collective Redress Model: An Opportunity for Strengthening Eastern Europe Countries' Access to Justice”, presented at the XXXIII Conference of the Kopaonik School of Natural Law - Slobodan Perović, held on 23 December 2020 and published in the Conference's articles collection, Zbornik radova 33. Susreta Kopaoničke škole prirodnog prava - Slobodan Perović, Unifikacija prava i pravna sigurnost, Tom IV, Beograd, 2020, 173-191. 
this task, the comparative method will be particularly helpful in analysing the solution which Countries more familiar with third party funding, like Australia, Canada or the United States have introduced or discussed.

Key words: collective redress, litigation funding, third party litigation funding, harmonisation, European Union

\section{INTRODUCTION}

Collective redress undoubtedly plays a pivotal role in the judicial enforcement of citizens' rights, particularly in the consumeristic field. Indeed, such an instrument has the potential to bring together a plethora of identical claims - often small - against economically powerful defendants. As a matter of fact, reaching a critical mass of claims might enable people to bring lawsuits that they would not have filed otherwise. In this sense, under a law and economics perspective, economies of scale render such a remedy particularly powerful and efficient. Moreover, such efficiency favours small plaintiffs, but it can also benefit the judicial system and the defendants: In fact, managing or defending only one complex litigation might be better than deciding or facing a multitude of related lawsuits, maybe even filed in different cities.

Therefore, collective actions have the merit of easing access to justice for citizens, to the point that this tool seems grounded in material equality provisions or access to justice rights recognized at the constitutional and international level. ${ }^{1}$ With regard to the European Union, reaching a common framework on consumer protection across Member States has always been regarded as a necessary target and the Union has encouraged actions in this sense. ${ }^{2}$ However, until 2020, compensatory collective redress - although of paramount importance in this field - has never been object of binding EU legislative instruments. ${ }^{3}$ Indeed,

1 Alberto Ronco, "L’azione di classe alla ribalta: l'egoismo necessario dell'attore", Giurisprudenza Italiana, No. 12, 2010, according to whom, collective redress is grounded in the material equality provision provided by article 3 of the Italian Constitution; Michael Legg, "Reconciling litigation funding and the opt out group definition in Federal Court of Australia class actions - the need for a legislative common fund approach", Civil Justice Quarterly, Vol. 31, 2011, 58. See, for instance, article 6 of the European Convention on Human Rights.

2 See, inter alia, Gian Antonio Benacchio, Diritto privato della Unione Europea, Cedam, Padova, 2016, 239-316.

3 In the field of injunctive collective redress was enacted Directive 2009/22/EC of the European Parliament and of the Council of 23 April 2009 on injunctions for the protection of consumers' interests, published in the OJ of the EU 1 May 2009, L 110/30. This Directive has now been repealed by Directive 1828/2020 (see footnote 10 below). 
only a Recommendation was issued in $2013^{4}$ and until then the field was left to a sort of regulatory competition regime among the various Member States. In this context, various reforms ensued, but each brought its own peculiarity, thus making the path towards an EU wide regime still farther away to reach. In particular, in 2014 the French legislator introduced the Action de groupe, ${ }^{5}$ while the Italian lawmaker, after various discussions, reformed its collective redress scheme in $2019,{ }^{6}$ by enlarging its scope and transplanting the postponed opt-in system from the French model. ${ }^{7}$ It is also noteworthy that an interesting collective action model was introduced in Slovenia in 2017.8 The latter reform implemented various solutions contained in the abovementioned 2013 Recommendation, and, beyond being an important achievement for the South-Eastern Europe legal en-

4 Commission Recommendation (2013/396/EU) of 11 June 2013 on common principles for injunctive and compensatory collective redress mechanisms in the Member States concerning violations of rights granted under Union Law, published in the OJ of the EU 26 July 2013, L 201/60. See also Csongor István Nagy, "The European collective redress debate after the European Commission's Recommendation: One step forward, two steps back?", Maastricht Journal of European and Comparative Law, Issue 4, Vol. 22, 2015, 530-552.

5 Law 2014-344 of 17 March 2014 (the so-called Loi Hamon), Journal officiel de la République française no. 0065 of 18 March 2014, page 5400. The Loi Hamon added articles from L623-1 to L623-32 in the French consumer code. The latter legislative provisions are supported, in the context of the same French Consumer Code, by the regulatory provisions provided for by articles from R623-1 to R623-33. See also the Circulaire du 26 septembre 2014 de présentation des dispositions de la loi n. 2014-344 du 17 mars 2014 relative à la consommation et du décret n. 2014-1081 du 24 septembre 2014 relatif à l'action de groupe en matière de consommation, published in the Bulletin officiel du Ministère de la Justice no. 2014-10 of 31 October 2014.

6 Law 12 April 2019, no. 31, Gazzetta Ufficiale 18 April 2019, no. 92. According to article 7 of law 31/2019 the reform should have entered into force on 19 April 2020. Such entry into force was then postponed to 19 May 2021 by article 26 of law-decree 9 November 2020, no. 149, Gazzetta Ufficiale 9 November 2020 no. 279. It is also worth noting that articles 139, 140 and 140-bis of the Italian consumer code have been explicitly abrogated by article 5 of the 2019 class action reform act. An exhaustive analysis of the reform can be found in Alessandro Palmieri, Legge n. 31/2019: la riforma della class action, UTET, Torino, 2019.

7 For a comparative analysis of the 2019 Italian collective action reform and the French Action de groupe, allow us to suggest Andrea Piletta Massaro, "The Italian class action reform: a redesigned tool beyond consumer law”, European Review of Private Law, Issue 4, Vol. 28, 2020, 841.

8 Law on Collective Actions (Zakon o kolektivnih tožbah - ZkolT), Official Journal of the Republic of Slovenia 6 October 2017, No. 55, available at https://www.uradni-list.si/_pdf/2017/Ur/ u2017055.pdf (accessed 24 September 2020). While analysing the Slovenian reform it is worth consulting Csongor István Nagy, "European models of collective actions", in Csongor István Nagy, Collective actions in Europe, Springer, Cham, 2019, 71-112; Jorg Sladič, "A new model of civil litigation in Slovenia: is the Slovenian judiciary prepared for the challenges presented by the new law on collective actions?", in Alan Uzelac and Cornelis Hendrik van Rhee (eds.), Transformation of civil justice. Unity and diversity, Springer, Cham, 2018, 213. 
vironment, it was the first act which provided for the issue of third-party litigation funding in the collective redress context. Finally, however, the European Union, in the context of the so-called New Deal for Consumers, ${ }^{9}$ decided to intervene in this field as well by enacting Directive 1828/2020. ${ }^{10}$ This directive introduces an EU-wide representative action scheme which can run in parallel with national systems. This parallel double-system, together with the choice of enacting a directive (thus a harmonisation and not a unification instrument) seems particularly appreciable, as it aims at introducing a common framework without eradicating the various national systems developed during the previous years. Moreover, the choice of the most appropriate tool will be left to European consumers, who will decide which means is more suitable to their claim among the European and the national systems.

However, one of the most noteworthy innovations introduced by Directive $1828 / 2020$ is a specific regime governing third-party litigation funding in the context of collective actions (article 10 of Directive 1828/2020). This instrument, as we will analyse more in-depth below, constitutes a fundamental complement to collective redress in easing citizens' access to justice. Indeed, plaintiffs may sometimes lack the necessary finances to bring a lawsuit or, although having the necessary funds available, they might still be unwilling to face the uncertainty of a proceeding and the potential consequent risk of paying the defendant's fees in case of defeat. Given such circumstances, the involvement of a third-party funder, willing to invest in the plaintiff's claim, might render access to justice easier and fairer. However, as we will see, third party litigation funding carries several issues that shall be regulated, possibly at the EU level.

The first part of the article will deliver an introduction to collective redress in Europe. The second and main part of the article will focus on third-party litigation funding of collective proceedings. Our analysis will start from Article 10 of Directive 1828/2020, compared with the relevant provisions of the 2013 Recommendation as well as the provisions on third-party funding contained in the 2017 Slovenian reform. However, as we will see, such legislation does not clarify all

9 An overview of the EU "New Deal for Consumers" is available at https://ec.europa.eu/info/ law/law-topic/consumers/review-eu-consumer-law-new-deal-consumers_en (accessed 24 February 2021).

10 Directive (UE) 2020/1828 of the European Parliament and of the Council of 25 November 2020 on representative actions for the protection of the collective interests of consumers and repealing Directive 2009/22/EC, published in the OJ of the EU 4 December 2020, L 409/1. The relevant European Parliament's press release is available at https://www.europarl.europa.eu/news/ en/press-room/20201120IPR92116/eu-consumers-will-soon-be-able-to-defend-their-rights-collectively (accessed 7 December 2020). 
the problematic aspects of this tool. As a consequence, under a comparative approach, we will analyse the solutions implemented in the systems which are more familiar with third-party funding, with a particular focus on the Australian legal system. ${ }^{11}$ In conclusion, we will reflect on how the new directive could improve European consumers' access to justice right and which amendments are still necessary, particularly in reference to innovations needed in the field of third-party litigation funding.

\section{DIRECTIVE 1828/2020: THROUGH A HARMONISED REGIME}

As clearly pointed out by recital 1 of Directive 1828/2020, the risk of unlawful practices which can have detrimental effects on consumers has been increased by the advent of digitalisation and globalisation. Thus, the need for a powerful instrument available to European consumers was perceived. To this purpose, recital 5 underlines how the previous Directive 2009/22/EC - limited to injunctive relief only - did not sufficiently address the challenges relating to the enforcement of consumer law. Moreover, recitals 6 and 7 note how the variety - or the absence - of collective redress models across the common market can obviously hamper consumer protection, and also diminish confidence in the internal market and the competition operating across it. The latter may also be distorted - without a proper collective redress means - by the unlawful practices carried out by some entrepreneurs vis-à-vis businesses behaving fairly in their activity (recital 2).

However, together with a strong concern for consumer protection, the $\mathrm{Di}$ rective is aware of the risk of increased abusive litigation and it aims at finding an equilibrium between this issue and improving access to justice (article 1 and recital 10). In any case such Directive can be seen both as a strong and as a soft harmonisation instrument. Indeed, as clearly stated in article 1, paragraph 2, it does not prevent Member States from adopting or retaining in force procedural means for the protection of collective interests of consumers at national level. Consequently, a common framework across the Union will be established, while retaining the interesting innovations introduced by Member States before this common framework was introduced. This is particularly noteworthy if we consider the limited' scope of Directive 1828/2020. Indeed, this newly introduced procedural means covers only the matters listed in the attached Annex I, which includes, in-

11 For an overview of the legislation regarding collective redress and third-party litigation funding worldwide see the report by Allianz Global Corporate \& Specialty SE, Collective Actions and Litigation Funding and the Impact on Securities Claims: A Global Snapshot, July 2020, available at https://www.agcs.allianz.com/content/dam/onemarketing/agcs/agcs/reports/AGCS-Collective-ActionsLitigation-Funding.pdf (accessed 28 February 2021). 
ter alia, unfair terms in consumer contracts, unfair commercial practices, liability for defective products, electronic commerce, credit agreements for consumers, data protection, supply of digital contents and digital services. All these matters are listed by referring to the relevant EU legislation. However, at first glance, an important absence is conspicuous: Directive 2014/104/EU ${ }^{12}$ on private enforcement of competition law is not mentioned, despite being one of the most prominent playgrounds for collective actions. Indeed, the very nature of competition law infringements renders such procedural means particularly helpful for harmed consumers. In addition, empirical data can confirm this strong relationship by showing how third-party funders are particularly involved in this field. ${ }^{13}$ As a consequence, the expunction of Directive 104/2014 from the scope of Directive 1828/2020 seems unjustified on a rational basis. ${ }^{14}$ However, and here we return to our discourse, the possibility of maintaining national regimes wider in scope might well protect the rights of the consumers who do not fall within the scope of the analysed Directive. Nevertheless, we cannot hide our criticism for the 'selfrestraint' approach used by the European legislator: A wider means, such as the 2019 Italian reform would have been preferable. In particular, the mentioned Italian model, aimed at reforming the $2009^{15}$ (with a 2012 update $^{16}$ ) one, extended the scope of collective action beyond consumer law, thus rendering such an instrument available generally, as shown by the placement of the new rules into the

12 Directive 2014/104/EU of the European Parliament and of the Council of 26 November 2014 on certain rules governing actions for damages under national law for the infringements of competition law provisions of the Member States and of the European Union, published in OJ of the EU 5 December 2014, L 349/1.

13 See Annex I to European Parliamentary Research Service, Research Paper, State of play of the EU private litigation funding landscape and the current EU rules applicable to private litigation funding, March 2021, 100, available at https://www.europarl.europa.eu/RegData/etudes/ STUD/2021/662612/EPRS_STU(2021)662612_EN.pdf(accessed 4 March 2021).

14 The inclusion of private enforcement of competition law in the scope of the directive was requested, inter alia, by The European Consumer Organisation (BEUC) in the position paper Proposal for a Directive on Representative Actions, 7-8, available at https://www.beuc.eu/publications/ beuc-x-2018-094_representative_actions_beuc_position_paper.pdf(accessed 26 February 2021).

15 Article 49, subsection 1, of Law 23 July 2009, no. 99, published in Gazzetta Ufficiale 31 July 2009, no. 176.

16 Article 6 of Law decree 24 January 2012, no. 1, published in Gazzetta Ufficiale 24 January 2012, no. 19. Then converted into Law 24 March 2012, no. 27, published in Gazzetta Ufficiale 24 March 2012, no. 71. For an exhaustive and reasoned overview (in English) on the previous Italian class action regime see Giorgio Afferni, "'Opt-in' class actions in Italy: Why are they failing”, Journal of European Tort Law, No. 1, Vol. 7, 2016, 82-100. 
Italian Code of Civil Procedure, ${ }^{17}$ whilst the previous provisions - limited to consumer law - were contained into the Consumer Code. ${ }^{18}$ Similarly, the French legislator, after issuing the Action de groupe in the interest of consumers in 2014, two years later ${ }^{19}$ enacted a similar general framework available in a plethora of fields. ${ }^{20}$ In the light of the example given by these noteworthy models, their transplant by the drafters of Directive 1828/2020 would have been advisable. Indeed, if the scope of such a Directive is harmonisation, why not harmonise the rules in one of the fields where collective actions are most intensively used? As an 'update' to the newly enacted Directive seems unlikely in the immediate future, the regulatory competition approach will continue with reference to collective redress and private enforcement of competition law.

Another interesting aspect of the newly introduced representative action model is the possibility of filing a cross-border action (article 6). This is probably one of the most important provisions, because it cannot be properly addressed by using the different Member States' regimes. In particular, article 6 grants standing to representative entities authorised in advance by Member States for the purpose of filing cross-border claims (according to article 5 of the Directive). In case consumers are harmed in different Member States, such entities are allowed to file a cross-border action also in a different Member State's Court.

In addition to the cross-border action option, Directive 1828/2020 got ahead of the EU's hostility for the opt-out adhesion scheme. Indeed, point 21 of the 2013 Recommendation was drafted clearly in favour of the opt-in mechanism, also by requiring that any exception to this principle [opt-in], by law or by court order, should be duly justified by reasons of sound administration of justice. ${ }^{21}$ Contrarywise, article 9, paragraph 2, of Directive 1828/2020 grants Member States free-

17 At articles from 840-bis to 840-sexiesdecies.

18 Legislative decree 6 September 2005, no. 206, Gazzetta Ufficiale 8 October 2005, no. 162, article 140-bis.

19 Loi 2016-1547 de modernisation de la justice du XXIe siècle, titre $V$, which introduced articles from 848 to 849-20 in the French code of civil procedure, as modified by the Décret 2019-1333 of 11 December 2019.

20 Articles from L 1134-6 to L 1134-10 of the Code du travail for actions in the field of labour discrimination (compensatory and injunctive); article L 142-3-1 of the Code de lenvironnement in the environmental field (compensatory and injunctive); chapter III, title IV, Ist book of the Code de la santé publique in the health safety field (compensatory); article 37, loi 78-17 of 6 January 1978 in the personal data protection field (injunctive).

21 The preference for the opt-in system was also justified by the principle of private autonomy in filing a claim. See, inter alia, C.I. Nagy, European Models of Collective Actions, op. cit., 24-30; Alexandra P. Mikroulea, "'Collective Redress' in European Competition Law”, Zeitschrift für Wettbewerbsrecht, Vol. 14(4), 2016, 392, 406-408. 
dom to adopt both an opt-in and an opt-out adhesion scheme. The only limit to opt-out left in the Directive's provisions is provided by paragraph 3 of the same article 9, requiring that a consumer resident in another Member State must adhere through an opt-in scheme only. This solution, inspired by a sort of certainty criteria, can be deemed reasonable and it has been transplanted from identical national provisions such as article 30, paragraph 3, of the 2017 Slovenian ZKoIT or Section 47B, point 11(b)(i) of the UK Competition Act 1998.

The possibility for Member States to implement Directive $1828 / 2020^{22}$ by choosing freely between an opt-in or an opt-out adhesion scheme will have, as we will analyse in-depth in the following paragraph, an important impact on how the relevant legislation shall be tailored with regard to one of the most innovative tools introduced by the analysed Directive, that is third-party litigation funding.

\section{THIRD-PARTY LITIGATION FUNDING MAKES ITS APPEARANCE IN DIRECTIVE 1828/2020: OPPORTUNITIES AND CHALLENGES}

Article 10 of Directive 1828/2020 regulates funding by third parties in the context of the new EU-wide representative action scheme. The issue is of particular importance - as explained in the introductory paragraph - because third-party funding is a fundamental tool in easing parties' access to justice and, if adopted in conjunction with collective redress, it can really boost the possibility of overcoming hurdles in filing claims by weak parties. ${ }^{23}$ Moreover, it may represent a valid instrument not only for small parties, but also for businesses, that, instead of financing directly the lawsuits they want to bring, may rely on funders, which, after a detailed due diligence of the claim, may finance it. Moreover, they can relieve the funded party from the loss occurred in case of defeat. Consequently, thirdparty funding may help businesses in externalising litigation costs, by not carrying them directly on their balance sheets.

However, all that glitters is not gold, and several issues arise out of third-party litigation funding, thus rendering its regulation necessary. First, some issues regarding the nature of the financing agreement between the funded party and the

22 Article 24 of Directive 1828/2020 provides that member States shall adopt the relevant implementation measures by 25 December 2022 and apply those measures from 25 June 2023.

${ }^{23}$ However, it is worth pointing out that funders generally invest in high-value claims which can deliver large profits. See Christopher Hodges, "Collective Redress: The Need for New Technologies”, Journal of Consumer Policy, Vol. 42, 2019, 62; Christopher Hodges, Stefan Vogenauer, Magdalena Tulibacka, "Costs and Funding of Civil Litigation: A Comparative Study", University of Oxford Legal Research Paper Series No. 55, 2009, 31, available at https://papers.ssrn.com/sol3/Delivery.cfm/ SSRN_ID1517183_code607218.pdf?abstractid=1511714\&mirid=1 (accessed 13 May 2021). 
funder can be noted, together with ethical aspects, such as the degree of intervention that the funder can exercise due to its position. The main concerns have recently attracted the attention of EU Institutions, particularly of the European Parliament, which issued a research paper in March 2021. ${ }^{24}$

This article will focus on features laying at the interconnection between third-party funding and collective redress. The following themes are of particular interest: A) judicial review of the funding agreement by a Court or Authority, specifically with reference to the fee charged by the funder; B) the likelihood of conflicts of interest between the funder and the parties involved and C) the binding effect of the funding agreement vis-à-vis the different adhesion methods, i.e., opt-in or opt-out.

Starting from the first two issues, these are partially addressed by article 10 of Directive 1828/2020. Indeed, the mentioned provision states that the representative entities' decisions must not be unduly influenced by funders in a manner that would be detrimental to the collective interests of the consumers concerned (paragraph 2.a). It is worth noting that such fundamental provision recalls point 16(a) of the 2013 Recommendation and a similar rule has recently been introduced by the new Dutch Collective Damages Act (WAMCA). ${ }^{25}$

Moreover, the Directive excludes the possibility of bringing a representative action against a defendant that is a competitor of the funding provider or against a defendant on which the funding provider is dependent (paragraph 2.b). Paragraph 3 of the same article 10 empowers Courts and Administrative Authorities to assess the compliance with the previously described provisions. To this end, qualified entities are required to disclose to the Court the financial resources received in support of the claim. The subsequent paragraph 4 provides that national implementation measures shall confer on the Courts or Administrative Authorities the power to require amendments to the relevant funding agreement or even reject the standing of qualified entities in the context of the representative action concerned.

The system adopted by means of Directive 1828/2020 has close resemblances with the suggestions contained in the 2013 Recommendation, which was, how-

24 European Parliamentary Research Service, Research Paper, State of play of the EU private litigation funding landscape and the current EU rules applicable to private litigation funding, March 2021, cit.

25 Dutch Collective Damages Act (WAMCA), article 1, entered into force on 1 January 2020. This article aims at preventing the funder from taking a leading influence over the claim. See the report on the Dutch WAMCA drafted by Linklaters LLP at https://www.linklaters.com/en/insights/publications/collective-redress/collective-redress-across-the-globe/the-netherlands (accessed 28 February 2021). 
ever, more complete. In particular, the Directive generally states that Member States shall ensure that [...] conflicts of interests are prevented, while point 15 of the 2013 Recommendation explicitly provided that in case of conflict of interest between the third party and the claimant, the Court should have the power to stay the relevant proceeding. In addition, the Recommendation granted the Court such a power also in case the third party had insufficient financial capability in respect of the commitments towards the claimant or the latter had insufficient resources to meet adverse costs of the procedure. However, while the first provision enshrined in point 15 of the Recommendation should also have been introduced in the Directive, the rules specifically related to financial capability of the funder and the claimant seem redundant and shall be considered included into the powers conferred on the Court in assessing the content of the financing agreement. Particularly, the provision related to the financial capability of the claimant seemed quite rhetoric, as one of the features of third-party funding is that the funder, after the abovementioned detailed due diligence, shall usually bear the adverse litigation costs if the case is lost. ${ }^{26}$ Indeed, such an agreement is sometimes meant as an investment by the funder into the plaintiff's claim. However, point 16 (c) of the 2013 Recommendation interestingly provides that the third-party funder shall not charge an excessive interest over the financing provided. In addition, point 32 of such Recommendation states that it shall be prohibited to base the interest charged by the funder on the claim's award unless that funding agreement is regulated by a public authority to ensure the interest of the parties.

The brief analysis above shows how the provisions about third-party funding contained in Directive 1828/2020 shall be deemed less complete than those proposed by means of the 2013 Recommendation, thus giving members States a broad margin of manoeuvre in the implementation process, whilst more precise provisions would have been more in line with the Directive's harmonisation aim. Indeed, some Member States may adopt stricter measures while others may opt for a low regulatory approach to third-party funding, thus leaving some degree of uncertainty in this field across the common market. On the contrary, we cannot deny the innovative impact of the provisions contained in Directive 1828/2020, as a European regulation of third-party funding was absent, and some common principles have now been provided. However, a more accurate and, maybe, courageous, approach would have been preferred. Anyhow, Member States may refer to a helpful precedent during the implementation phase: We are referring to

${ }^{26}$ European Parliamentary Research Service, Research Paper, State of play of the EU private litigation funding landscape and the current EU rules applicable to private litigation funding, March 2021, cit., 66 . 
the only Member State which - by taking inspiration from the 2013 Recommendation - introduced a complete regulation of third-party funding in the collective redress context, that is Slovenia by means of the abovementioned ZKoIT.

\section{THE FIRST REGULATION OF THIRD-PARTY FUNDING AND COLLECTIVE REDRESS IN THE EU: THE SLOVENIAN ZKOIT}

The 2017 reform introduced by the Slovenian legislator provides for a precise regulation of third-party litigation funding in the collective redress context. However, before analysing such regulation, we deem it appropriate to briefly introduce the main features of the ZKoIT, which was enacted in 2017 and entered into force in April 2018.

The Slovenian legislator passed the ZKoIT with the purpose of easing access to justice for citizens, as clearly declared by article 1 of the reform. Article 2 defines the scope of application, which includes consumer law, but, noteworthily, goes beyond it, as it is applicable - inter alia - also in the fields of competition law, environmental protection, securities, labour and anti-discrimination law. ${ }^{27}$ According to article 4, a collective lawsuit may be filed both by a representative organisation and by the attorney general. This aspect, from the standpoint of a Western Europe observer, might seem a little strange, because it implies a sort of State's involvement in private litigation affairs, which is normally accepted only in particular and sensitive circumstances. However, such a peculiarity of the Slovenian model represents a bridge between two traditions, besides an optimal equilibrium point between them. ${ }^{28}$ Indeed, a sort of public enforcement of private rights matrix is quite commonly accepted in Eastern Europe's legal tradition. In this context, the standing rule provided by article 4 of the ZKoIT represents a very smart point of equilibrium.

With regard to the adhesion mechanism - which is particularly important in the third-party funding discourse - article 29 ZKoIT provides for both opt-in and opt-out, by allowing the competent Court to decide which one is the most

${ }^{27}$ In this field only collective injunctions are available. See C.I. Nagy, European models of collective actions, op. cit., 87, footnote no. 137.

28 On this topic, allow us to refer to the Author's reflections expressed in the Kopaonik Conference's article "Towards an EU-Wide Collective Redress Model: An Opportunity for Strengthening Eastern Europe Countries' Access to Justice", op. cit., 188. The prevalence of public enforcement in Central and Eastern Europe's countries is also expressed by Katalin J. Cseres, "Harmonising Private Enforcement of Competition Law in Central and Eastern Europe: The Effectiveness of Legal Transplants through Consumers Collective Actions", Yearbook of Antitrust and Regulatory Studies, Issue 12, 2015, 33, 54. 
appropriate for the case at stake. However, as previously reported and in line with Directive 1828/2020, article 30 excludes the possibility of adopting the opt-out scheme for subjects not resident within the Slovenian borders.

Third-party funding is regulated by articles 59, 60 and 61 ZKoIT. In particular, article 59 - which is clearly inspired by points 15 and 16 of the 2013 Recommendation - provides for a disclosure duty on part of the plaintiffs with regard to the relevant sources of financing (paragraph 1). This disclosure requirement is also present in article 10 of Directive 1828/2020, although some issues should have been better clarified. However, the extent of this disclosure duty is not clear, i.e. it is unclear whether the funding details must be disclosed to the Court only or also to the counterparty. In this sense, recital 52 of Directive 1828/2020 seems to prefer the first solution by requiring that representative entities should be fully transparent vis-à-vis courts or administrative authorities with regard to the source of funding. However, a broader approach to the disclosure phase is envisaged by rule 237 of the ELI/Unidroit Model European Rules of Civil Procedure, which requires that such details may be disclosed to the Court and in so far as appropriate, to the parties. ${ }^{29}$

In case a conflict of interest may emerge from the abovementioned disclosure phase, or in case the third party or the claimant do not have the necessary financial capability, the Court shall not certify the action (paragraph 2). In addition, paragraph 3 prevents the funder from both unduly influencing the course of the action and funding an action against a competitor or a subject on which it is dependent. Finally, the funder shall not charge an excessive interest, which, in quantitative terms, means that the interest cannot exceed the legal interest rate. Given the absence of such a provision in the newly enacted Directive 1828/2020, the Slovenian prohibition on the funder's excessive interest may well represent a viable model for safeguarding the funded parties' interest vis-à-vis the funder. However, in addition to the Slovenian example, a more flexible model, which can be adopted while implementing the new Directive's rules, can be framed by granting the Court powers to check not only the funding agreement's formal requirements listed in the Directive, but also the interest rate charged by the funder. ${ }^{30} \mathrm{In}$

29 ELI/Unidroit Model European Rules of Civil Procedure, approved in 2020 and available at https://www.unidroit.org/instruments/civil-procedure/eli-unidroit-rules (accessed 28 February 2021).

30 As a matter of fact, empirical evidence suggests that the percentage paid to the funder is inversely proportional to the value of the relevant claim. See Christopher Hodges, John Peysner, Angus Nurse, "Litigation Funding: Status and Issues", University of Oxford Legal Research Paper Series No. 49, 2012, 41, available at https://papers.ssrn.com/sol3/Delivery.cfm/SSRN_ID2126506_ code468680.pdf?abstractid=2126506\&mirid=1 (accessed 13 May 2021). 
this sense, the Canadian precedent in Houle $v$ St. Jude Medical, ${ }^{31}$ can be taken as a parameter. In this case, the Ontario Superior Court of Justice stated that in order to approve a funding agreement, the Court must check, beyond the circumstances that the agreement eases access to justice and does not raise conflicts of interest, that the third-party funder must not be overcompensated. ${ }^{32}$ The latter approach - instead of the more rigid Slovenian one - might be preferable, because the limitation of funders' overcharges is quite controversial. Indeed, if an excessive interest rate in favour of the funder might seem unjust, on the other side it is preferable that citizens might have the possibility to file their claims thanks to the funder's intervention than not file them at all. ${ }^{33}$ Also from a law and economics perspective, externalities seem to be lower in the first scenario than in the noclaim one. Consequently, a case-by-case flexible approach managed by the Court seems more suitable to the issue at stake than a fixed parameter.

Article 60, with regard to expenses, clearly outlines that funded collective claims rely on the loser pays principle, as well.

Article 61, which is quite innovative in the European context, deals with the attorney's fees payment. Interestingly, paragraph 1 provides that the plaintiff's lawyer can arrange a contingency fee agreement not exceeding $15 \%$ of the sum recovered by means of the action. However, this percentage can be increased up to $30 \%$, should the lawyer accept to bear all the expenses in case of defeat. Such an innovative mechanism can be defined as a sui generis attorney third party litigation funding. ${ }^{34}$ This shall be regarded as an alternative means of financial support for collective actions, that may prove helpful in small claims, where a big funder might not be interested, whilst the plaintiff's lawyer may be attracted by the possible higher return and decide to make such an investment, which, in part, relies on its case-management conduct.

31 Ontario Superior Court of Justice, Houle v St. Jude Medical, (2017 ONSC 5129), available at $h t t p: / / c a n l i i . c a / t / h 5 n n m$ (accessed 28 February 2021). See also U.S. Chamber Institute for Legal Reform, Uncharted Waters, An Analysis of Third Party Litigation Funding in European Collective Redress, October 2019, 27, 82-83, available at https://instituteforlegalreform.com/research/unchartedwaters-analysis-of-tplf-in-european-collective-redress/ (accessed 28 February 2021); Gian Marco Solas, Third Party Funding. Law, Economics and Policy, Cambridge University Press, Cambridge, 2019, 47-48.

32 OSCJ, Houle v St. Jude Medical, paragraph 63.

33 European Parliamentary Research Service, Research Paper, State of play of the EU private litigation funding landscape and the current EU rules applicable to private litigation funding, March 2021, cit., 79, see in particular footnote 144 .

34 U.S. Chamber Institute for Legal Reform, Uncharted Waters, An Analysis of Third Party Litigation Funding in European Collective Redress, cit., 73. 
After the previous paragraph, a question arises: Is the Slovenian approach, which explicitly allows contingency fees - a typical US-style class action feature - in line with the European collective redress tradition? The European hostility vis-à-vis contingency fees seems rooted. ${ }^{35}$ Indeed, point 30 of the 2013 Recommendation explicitly prohibited contingency fees, except in case they are properly regulated by a national legislation which considers the right to full compensation of the claimants. Similarly, the European Parliament's Legislative resolution of 26 March 2019, a preparatory work on the path to Directive 1828/2019, in the proposed article $15 \mathrm{a}$, explicitly prohibited the introduction of a contingency fee mechanism. ${ }^{36}$ However, the final version of Directive 1828/2020, which is silent on this point, seems to have implicitly expunged such a prohibition, thus allowing Member States to introduce contingency remuneration, as previously done by the Slovenian legislator. However, given the still cold acceptance of such feature in the European context, a proper national regulation, as envisaged by the 2013 Recommendation, is advisable for Member States willing to introduce contingency fees into their collective action scheme. In this sense, the 2019 Italian reform - despite not introducing a proper contingency fee system - has adopted a sort of rewarding remuneration for lawyers. ${ }^{37}$

After having provided an overview of the Slovenian class action scheme, with particular reference to the regulation of third-party litigation funding, it is worth focusing our analysis on how the adoption of an opt-in or an opt-out adhesion scheme may influence the effectiveness of third-party funding and how a proper collective action regime might consequently be tailored.

\section{OPT-IN OR OPT-OUT: WHICH ADHESION SCHEME IS MORE APPROPRIATE FOR THIRD-PARTY LITIGATION FUNDING?}

The adhesion mechanism embodies a key aspect of a collective action model. As anticipated, two main systems are used in collective action models world-

35 Christopher Hodges, “Collective Redress in Europe: The New Model”, Civil Justice Quarterly, Vol. 3, 2010, 373.

36 European Parliament, Legislative resolution of 26 March 2019 on the proposal for a directive on representative actions for the protection of the collective interests of consumers, 2018/0089 (COD), available at https://www.europarl.europa.eu/doceo/document/TA-8-2019-0222_ EN.html?redirect (accessed 26 February 2021).

37 Future article 840-novies of the Italian Code of Civil Procedure. See Claudio Consolo, "La terza edizione della azione di classe è legge ed entra nel C.P.C. Uno sguardo d'insieme ad una amplissima disciplina", Corriere Giuridico, No. 6, 2019, 737; Giulio Ponzanelli, "La nuova class action", Danno e Responsabilità, No. 3, 2019, 306. 
wide, i.e., opt-in and opt-out. In a nutshell, the first method enables subjects bearing an interest in the claim to join the action only by means of a specific adhesion, which can occur at the beginning or at a later stage of the proceeding, as we will see shortly below. Contrariwise, through an opt-out system, the decision that defines the lawsuit is binding upon all the members of the category involved, without needing their express consent. As mentioned, variations of those systems created some sort of hybrids between opt-in and opt-out. For instance, the postponed opt-in introduced by the French action de groupe and now also adopted by the 2019 Italian reform attempts to strike a balance between the pros and cons of the two main adhesion mechanisms. Indeed, while through an opt-in system a class action is more manageable, more respectful of the private autonomy principle and less prone to abusive litigation risks, such a mechanism may pose the risk of not including all the injured parties into the class (for different reasons, e.g., they were not informed about the claim, the adhesion phase is set before the judgement of the case, thus discouraging adhesions, etc.). On the contrary, an opt-out system has the merit of including all the injured class' members, but it is less manageable. The mentioned postponed opt-in combines the management of a defined class with the opportunity to adhere after a decision on the merits of the claim has been issued, thus incentivizing injured parties in joining the action.

The described mechanisms' characteristics play a fundamental role in the context of third-party funding. Indeed, while an opt-in system may ease the management of the parties' adhesion to funding agreement (i.e. if the lawsuit is funded by a third party, adherents, while joining the class, must also accept the funding agreement), an opt-out system, although more powerful in easing access to justice - an aim of third-party funding - poses the risk of free riding. ${ }^{38}$ In fact, if class members are automatically included into the class defined after the decision on the claim, they might well attempt to receive their compensation without joining the funding agreement (and, consequently, obtain a full refund, avoiding a deduction of the funder's fee).

The abovementioned issues related to third-party funding and adhesion mechanisms have not been addressed by rules or solutions in the European context, thus requiring a comparative approach to identify the proper solutions. Useful hints may be found in the US, Canadian and Australian experiences.

38 Brian T. Fitzpatrick, "Can and Should the New Third-Party Litigation Financing Come to Class Actions?”, Theoretical Inquiries in Law, No. 1, Vol. 19, 2018, 117-118; M. Legg, 2011, op. cit., 60-61; Deborah R. Hensler, "From Sea to Shining Sea: How and Why Class Actions Are Spreading Globally”, Kansas Law Review, Vol. 65, 2017, 978. 
First, the US experience - which represents the most renowned example of opt-out system - in order to prevent free riding, has elaborated a theory based upon the unjust enrichment doctrine, commonly recognized by US Courts with regard to lawyers' fees. ${ }^{39}$ In particular, according to such a theory, it is unjust that class members take the benefit without paying the lawyers who helped them obtain it. Consequently, some scholarly contributions have suggested extending such a doctrine also to third funders. ${ }^{40}$ In a similar vein, in Ontario, judges are granted the power to bind putative class members to third-party litigation funding agreements. ${ }^{41}$

However, the solutions adopted in the Australian context seem to be characterised by more interesting aspects. Third-party funding in Australian class actions has first been allowed by the Fostif decision issued in 2006 by the High Court of Australia. ${ }^{42}$ Since then, as effectively pointed out by Michael Legg and Samuel J. Hickey, third-party funding has become synonymous with class action litigation in Australia..$^{43}$ In fact, these Authors define such market as a continuously expanding one, where, prior to May 2017, 22 per cent out of the 513 class actions filed were funded. ${ }^{44}$ Anyhow, the problem of reconciling third-party funding with the opt-out Australian class action model was prominent and some interesting solutions have been adopted by Courts or suggested by research reports on this matter. The first approach elaborated by the Australian system was the so-called closed class, introduced by the Full Federal Court's Multiplex decision in 2007. ${ }^{45}$

39 B.T. Fitzpatrick, op. cit., 117-118, see, in particular, the case law reported in footnotes $24-26$ therein.

40 Ibidem, 118.

41 Ibidem. See also Jasminka Kalajdzic, Peter Cashman, Alana Longmoore, "Justice for Profit: A Comparative Analysis of Australian, Canadian and U.S. Third Party Litigation Funding", The American Journal of Comparative Law, No. 1, Vol. 61, 2013, 115-116.

42 High Court of Australia, 30 August 2006, Campbells Cash \& Carry Pty Ltd v Fostif Pty Ltd, [2006] HCA 41, available at http://eresources.hcourt.gov.au/downloadPdf/2006/HCA/41 (accessed 28 February 2021). See also Michael Legg, Samuel J. Hickey, "Class Actions in Australia", Brian T. Fitzpatrick, Randall S. Thomas (eds.), The Cambridge Handbook of Class Actions, Cambridge University Press, Cambridge, 2021, 376; M. Legg (2011), op. cit., 52; G.M. Solas, Third Party Funding. Law, Economics and Policy, op. cit., 41.

${ }^{43}$ M. Legg and S.J. Hickey, op. cit., 375.

44 Ibidem.

45 Federal Court of Australia, Full Court, 21 December 2007, Multiplex Funds Management Ltd v P Dawson Nominees Pty Ltd, (2007) 164 FCR 275. See Australian Law Reform Commission (ALRC), Integrity, Fairness and Efficiency-An Inquiry into Class Action Proceedings and Third-Party Litigation Funders, Final Report, December 2018, 67, point 2.72, available at https://www.alrc.gov.au/ 
This solution allows Courts to limit the class' perimeter only to members who have signed the relevant funding agreement. However, this approach - although it boasts some practical positive features - has nevertheless raised some concerns related to the soul of the Australian class action system, conceived as an opt-out model aimed at easing citizens' access to justice. Consequently, turning it into a sort of opt-in model when a litigation funder is involved might be perceived as a deviation from the original model and its intent. Moreover, an additional concern regards the possibility of parallel proceedings, whose number has increased after the Multiplex ruling: ${ }^{46}$ In fact, if a class is closed, harmed subjects who have not taken part in the funded lawsuit may well initiate other proceedings, thus leading to a less efficient case management system, which can also be burdensome for defendants involved in an undefined number of proceedings. ${ }^{47}$ This aspect, as well explained by Legg and Hickey, undercuts the economies of scale that represent one of the key benefits of aggregate litigation. ${ }^{48}$

An attempt to go beyond the hurdles described above is the allowance of the so-called common fund orders. Such a mechanism was first authorised by the Full Federal Court in the 2016 Money Max decision. ${ }^{49}$ In a nutshell, this mechanism allows the Court to issue an order which authorises the funder's payment from the total sum awarded by the Court, irrespectively of the fact that class members entered into the relevant funding agreement. ${ }^{50}$ Such an approach, though, see-

wp-content/uploads/2019/08/alrc_report_134_webaccess-1.pdf(accessed 28 February 2021); M. Legg and S.J. Hickey, op. cit., 377-379; M. Legg, 2011, op. cit., 57; Roger Gamble, "Jostling for a larger piece of the (class) action: Litigation funders and entrepreneurial lawyers stake their claims", Common Law World Review, Issue 1, Vol. 46, 2017, 6-8; Stefaan Voet, "The Crux of the Matter: Funding and Financing Collective Redress Mechanisms", Burkhard Hess, Maria Bergström, Eva Storskrubb (eds.), EU Civil Justice: Current Issues and Future Outlook, Hart Publishing, Oxford, 2016, 220.

46 M. Legg and S.J. Hickey, op. cit., 379.

47 M. Legg, 2011, op. cit., 62.

48 M. Legg and S.J. Hickey, op. cit., 379.

49 Federal Court of Australia, Full Court, 26 October 2016, Money Max Int Pty Ltd (Trustee) $v$ QBE Insurance Group Ltd, (2016) 245 FCR 191. See European Parliamentary Research Service, Research Paper, State of play of the EU private litigation funding landscape and the current EU rules applicable to private litigation funding, March 2021, cit., 80-81; M. Legg and S.J. Hickey, op. cit., 279; Michael Legg, "Litigation funding of Australian class actions after the High Court rejection of common fund orders: BMW Australia Ltd v Brewster; Westpac Banking Corporation v Lenthall [2019] HCA 45", Civil Justice Quarterly, 2020, 39(4), 308.

50 European Parliamentary Research Service, Research Paper, State of play of the EU private litigation funding landscape and the current EU rules applicable to private litigation funding, March 2021, cit., 80-81; M. Legg, S.J. Hickey, op. cit., 379; M. Legg (2020), op. cit., 309. 
med to have been ruled out by the High Court of Australia in the 2019 Brewster and Lenthall decision. ${ }^{51}$ However, a meticulous analysis of this ruling shows how the decision excluded the Court's power to issue common fund orders only during the initial stage of the proceeding. Indeed, orders at the initial stage of a proceeding shall address preliminary issues aimed at ensuring that justice is done in a representative proceeding, ${ }^{52}$ whilst the Court found that a common fund order at the initial stage of the proceeding does not fall within this definition. ${ }^{53}$ Consequently, Courts shall retain this power at a later stage of the proceeding, as confirmed in 2020 by the Full Federal Court in the Davaria decision ${ }^{54}$ and by the New South Wales Court of Appeal while ruling on the same Brewster case. ${ }^{55}$ Therefore, common fund orders have not been ruled out and they can keep being regarded as a viable means for striking a balance between third-party funding and the optout adhesion mechanism.

Finally, in light of the above-described judicial decisions, some reports have suggested the Australian Government the enactment of a specific discipline concerning common fund orders. In particular, the Australian Law Reform Commission (ALRC) Report suggested that such orders should be supported by an express statutory power. ${ }^{56}$ Similarly, the report issued by the Parliamentary Joint Committee on Corporations and Financial Services, after stating that the availability of a common fund order at the end of a proceeding promotes outcomes which are reasonable, proportionate and fair for all class members as all who financially benefit from the class action are required to contribute to the costs occurred, ${ }^{57}$

51 High Court of Australia, 4 December 2019, BMW Australia Ltd v Brewster \& Anor and Wastpac Banking Corporation \& Anor v Lenthall \& Ors, [2019] HCA 45, available at http://eresources.hcourt.gov.au/downloadPdf/2019/HCA/45 (accessed 28 February 2021).

52 Ibidem, point 125.

53 Ibidem, inter alia, points 53, 93. See also M. Legg, 2020, op. cit., 311-312.

54 Federal Court of Australia, Full Court, 3 November 2020, Davaria Pty Limited $v$ 7-Eleven Stores Pty Ltd, [2020] FCAFC 183.

55 NSW Court of Appeal, 30 October 2020, Brewster v BMW Australia Ltd, [2020] NSWCA 272.

56 ALRC Report, 99, point 4.35.

57 Parliamentary Joint Committee on Corporations and Financial Services, Litigation funding and the regulation of the class action industry, December 2020, 125, point 9.123, available at https://www.aph.gov.au/-/media/Committees/corporations_ctte/Litigation_Funding/Litigation_ funding_and_the_regulation_of_the_class_action_industry_report.pdf?la=en\&hash $=688$ F6CEDD01 6BE31B03A75101A6C6AA3BAE29AB7 (accessed 28 February 2021). 
concluded by recommending the Australian Government to legislate in order to address uncertainty in relation to common fund orders..$^{58}$

Approached as providing suggestive ideas, and as a possible inspiration for European legislators called to implement Directive 1828/2020 into Member States' legal systems, the common fund approach must not be regarded as exclusive to common law systems dealing with opt-out class actions and third-party funding. Indeed, rule 238, paragraph 2, of the ELI/Unidroit Model European Rules of Civil Procedure states that in case of successful proceeding, the total amount of compensation received by the qualified claimant shall form a common fund. Moreover, paragraph 3 of the same rule 238 specifies that the representative entity's costs and expenses must be paid from the common fund before any distribution of compensation to group members. To this purpose, considering the relevant funder's fee included into the costs and expenses referred to in rule 238, paragraph 3 , seems reasonable. ${ }^{59}$

In conclusion, the abovementioned considerations expressed by the Australian Parliamentary Joint Committee on Corporations and Financial Services with regard to third-party litigation funding's positive effects well embody its importance in the collective redress discourse. Consequently, a proper balance between such a tool and the various adhesion mechanisms shall be struck. It is reasonable to consider that in an opt-in collective proceeding a sort of automatic 'closed class' is established. Contrariwise, in an opt-out scheme, the most appropriate means to address the reported concerns is the regulation of a proper common fund regime.

\section{CONCLUSION: A ROLE TO PLAY FOR COMPARATIVE LAW}

Collective actions are expected to play an ever-increasing central role in the protection of consumers' and citizens' rights in the near future. Such a prediction seems confirmed by the enactment of Directive 1828/2020. Although this legislation bears some limitations, such as the applicability in the sole consumeristic field, it represents a first step towards harmonisation throughout the European

58 Ibidem, 125, point 9.124, suggests addressing the issue in accordance to the High Court's decisions in Brewster and Lenthall. However, such clarification, if read systematically with the previous paragraph, concludes in favour of common fund orders' availability at a later stage of the proceeding.

59 European Parliamentary Research Service, Research Paper, State of play of the EU private litigation funding landscape and the current EU rules applicable to private litigation funding, March 2021, cit., 81 . 
Union. In addition, Directive 1828/2020 contains some innovative features, such as the possibility to adopt an opt-out adhesion system as well as an embryonal regulation of third-party litigation funding in the collective redress context. Both these tools aim at empowering the harmed subjects' access to justice by removing the procedural and financial hurdles they may face. However, third-party funding is not well-developed in the European context. Before the enactment of Directive 1828/2020 it was only addressed in the context of collective redress by the 2013 Recommendation, which influenced the Slovenian legislator while drafting the ZKoIT, maybe the most complete European legislative instrument on the topic.

Nevertheless, Directive 1828/2020 does not regulate some issues, such as the interaction between adhesion mechanisms and third-party funding, which, given that the EU's ban on opt-out has ceased, is of paramount importance. In such a context, where almost all Member States will have to draft rules on this topic, the role of comparative law will be central. Indeed, a study of experiences where third-party funding is commonly used may well prove useful. In particular, the Australian experience, with the closed class and the common fund solutions, needs to be clearly in the mind of Member States' legislators while implementing Directive 1828/2020 into their legal systems. Moreover, comparative law can play a fundamental role also through model rules like the ELI/Unidroit Model European Rules of Civil Procedure.

ANDREA PILETTA MASSARO

Istraživač na Univerzitetu u Torinu

Doktorand Univerziteta u Trentu

\title{
NOVA EU DIREKTIVA O KOLEKTIVNIM TUŽBAMA I FINANSIRANJE VOĐENJA PARNIČNOG POSTUPKA SREDSTVIMA TREĆIH LICA: PRILIKA ZA EVROPSKE POTROŠAČE
}

\author{
Rezime
}

\begin{abstract}
Nakon što je godinama obeštećenje putem kolektivne tužbe bilo prepušteno nekoj vrsti regulatornog nadmetanja među državama članicama, Direktivom 1828/2020 je konačno na nivou cele EU uveden mehanizam kolektivne tužbe, sa ciljem da ojača položaj evropskog potrošača u novim tržišnim kretanjima u uslovima globalizacije i digitalizacije. Ovaj novi sistem, koji će funkcionisati paralelno sa domaćim sredstvima, uvodi neke novine kao što je mehanizam prekogranične tužbe, mogućnost usvajanja opt-out modela i specifična pravila u pogledu finansiranja vođenja parnice sredstvima trećih lica u kontekstu kolektivne tužbe. Ovaj element, kojim su se još bavile Preporuke iz 2013, od posebnog je interesa, jer finansiranje od strane trećih lica predstavlja naročito snažno
\end{abstract}


sredstvo u kontekstu kolektivnog postupka kojim se građanima olakšava pristup pravdi. Međutim, pravila koja uvodi Direktiva 1828/2020 ostavljaju neka pitanja otvorenim. Konkretno, uloga suda u koracima koji se preduzimaju u pogledu sporazuma o finansiranju sa posebnim osvrtom na naknadu pružaoca finansiranja, kao i dejstvo sporazuma o finansiranju pri izboru opt-out mehanizma su od najvećeg značaja i zahtevaju dodatna tumačenja. U tom kontekstu, komparativni pristup biće od naročite pomoći u analizi rešenja koje su uvele ili razmatrale države s više iskustva sa finansiranjem sredstvima trećih lica, kao što su Australija, Kanada ili SAD.

Ključne reči: kolektivna tužba, finansiranje vođenja parnice, finansiranje vođenja parnice sredstvima trećih lica, harmonizacija, Evropska unija

\section{Bibliography}

Afferni G., "'Opt-in' class actions in Italy: Why are they failing", Journal of European Tort Law, No. 1, Vol. 7, 2016.

Allianz Global Corporate \& Specialty SE, Collective Actions and Litigation Funding and the Impact on Securities Claims: A Global Snapshot, July 2020, https://www.agcs.allianz.com/content/dam/onemarketing/agcs/agcs/reports/AGCS-Collective-Actions-Litigation-Funding.pdf.

Australian Law Reform Commission (ALRC), Integrity, Fairness and Efficiency-An Inquiry into Class Action Proceedings and Third-Party Litigation Funders, Final Report, December 2018, https://www.alrc.gov.au/wp-content/uploads/2019/08/alrc_report_134_webaccess-1.pdf.

Australian Parliamentary Joint Committee on Corporations and Financial Services, Litigation funding and the regulation of the class action industry, December 2020, https:// www.aph.gov.au/-/media/Committees/corporations_ctte/Litigation_Funding/Litigation_funding_and_the_regulation_of_the_class_action_industry_report.pdf?la=en\& hash=688F6CEDD016BE31B03A75101A6C6AA3BAE29AB7.

Benacchio G. A., Diritto privato della Unione Europea, Cedam, Padova, 2016.

Consolo C., "La terza edizione dell'azione di classe è legge ed entra nel c.p.c. Uno sguardo d'insieme ad una amplissima disciplina", Corriere Giuridico, No. 6, 2019.

Cseres K. J., "Harmonising private enforcement of competition law in Central and Eastern Europe: The effectiveness of legal transplants through consumer collective actions", Yearbook of Antitrust and Regulatory Studies, Issue 12, 2015.

D’Alessandro E., (ed.), Prospettive del third party funding in Italia, Ledizioni, Milano, 2019.

European Consumer Organisation (BEUC) position paper Proposal for a Directive on Representative Actions, https://www.beuc.eu/publications/beuc-x-2018-094_representative_actions_beuc_position_paper.pdf.

European Parliamentary Research Service, Research Paper, State of play of the EU private litigation funding landscape and the current EU rules applicable to private litigation funding, March 2021, https://www.europarl.europa.eu/RegData/etudes/ STUD/2021/662612/EPRS_STU(2021)662612_EN.pdf. 
Fitzpatrick B. T., "Can and Should the New Third-Party Litigation Financing Come to Class Actions?", Theoretical Inquiries in Law, No. 1, Vol. 19, 2018.

Gamble R., "Jostling for a larger piece of the (class) action: Litigation funders and entrepreneurial lawyers stake their claims”, Common Law World Review, Issue 1, Vol. 46, 2017.

Hensler D. R., "From Sea to Shining Sea: How and Why Class Actions Are Spreading Globally", Kansas Law Review, Vol. 65, 2017.

Hodges C., "Collective redress in Europe: The New Model", Civil Justice Quarterly, Vol. 3, 2010.

Hodges C., "Collective Redress: The Need for New Technologies", Journal of Consumer Policy, Vol. 42, 2019.

Hodges C., Peysner J., Nurse A., "Litigation Funding: Status and Issues", University of Oxford Legal Research Paper Series No. 49, 2012, https://papers.ssrn.com/sol3/Delivery.cfm/SSRN_ID2126506_code468680.pdf?abstractid=2126506\&mirid=1.

Hodges C., Vogenauer S., Tulibacka M., "Costs and Funding of Civil Litigation: A Comparative Study", University of Oxford Legal Research Paper Series No. 55, 2009, https:// papers.ssrn.com/sol3/Delivery.cfm/SSRN_ID1517183_code607218.pdf?abstractid=151 $1714 \&$ mirid $=1$.

Kalajdzic J., Cashman P., Longmoore A., "Justice for Profit: A Comparative Analysis of Australian, Canadian and U.S. Third Party Litigation Funding", The American Journal of Comparative Law, No. 1, Vol. 61, 2013.

Legg M., Hickey S. J., “Class Actions in Australia”, Fitzpatrick B.T., Thomas R.S. (eds.), The Cambridge Handbook of Class Actions, Cambridge University Press, Cambridge, 2021.

Legg M., "Litigation funding of Australian class actions after the High Court rejection of common fund orders: BMW Australia Ltd v Brewster; Westpac Banking Corporation v Lenthall [2019] HCA 45", Civil Justice Quarterly, 2020.

Legg M., "Reconciling litigation funding and the opt out group definition in Federal Court of Australia class actions - the need for a legislative common fund approach", Civil Justice Quarterly, Vol. 31, 2011.

Mikroulea A. P., “'Collective Redress' in European Competition Law”, Zeitschrift für Wettbewerbsrecht, Vol. 14 (4), 2016.

Nagy C. I., "European models of collective actions", in C. I. Nagy, Collective actions in Europe, Springer, Cham, 2019.

Nagy C. I., “The European collective redress debate after the European Commission's Recommendation: One step forward, two steps back?", Maastricht Journal of European and Comparative Law, Issue 4, Vol. 22, 2015.

Palmieri A., Legge n. 31/2019: la riforma della class action, UTET, Torino, 2019. 
Piletta Massaro A., "The Italian class action reform: a redesigned tool beyond consumer law”, European Review of Private Law, Issue 4, Vol. 28, 2020.

Piletta Massaro A., "Towards an EU-Wide Collective Redress Model: An Opportunity for Strengthening Eastern Europe Countries' Access to Justice”, Zbornik radova 33. Susreta Kopaoničke škole prirodnog prava - Slobodan Perović, Unifikacija prava i pravna sigurnost, Tom IV, Beograd, 2020, 173-191.

Poncibò C., "Prime riflessioni sulla tutela giuridica integrata dei diritti dei consumatori nel diritto europeo", in P. Cendon (ed.), Responsabilità civile - Volume primo, Cedam, Padova, 2020.

Ponzanelli G., "La nuova class action”, Danno e Responsabilità, No. 3, 2019.

Ronco A., "Lazione di classe alla ribalta: l'egoismo necessario dell'attore", Giurisprudenza Italiana, No. 12, 2010.

Scarchillo G., Class action. Dalla comparazione giuridica alla formazione del giurista: un caleidoscopio per nuove prospettive, Giappichelli, Torino, 2019.

Sladič J., "A new model of civil litigation in Slovenia: is the Slovenian judiciary prepared for the challenges presented by the new law on collective actions?", in Uzelac A. and van Rhee C. H. (eds.), Transformation of civil justice. Unity and diversity, Springer, Cham, 2018.

Solas G. M., Third Party Funding. Law, Economics and Policy, Cambridge University Press, Cambridge, 2019.

U.S. Chamber Institute for Legal Reform, Uncharted Waters, An Analysis of Third Party Litigation Funding in European Collective Redress, October 2019, https://instituteforlegalreform.com/research/uncharted-waters-analysis-of-tplf-in-european-collective-redress/.

Voet S., "The Crux of the Matter: Funding and Financing Collective Redress Mechanisms", Burkhard Hess, Maria Bergström and Eva Storskrubb (eds.), EU Civil Justice: Current Issues and Future Outlook, Hart Publishing, Oxford, 2016.

Article history

Received: 21.04.2021.

Accepted: 14.05.2021.

ORIGINAL SCIENTIFIC PAPER 